\title{
SEROPREVALANCE AND MOLECULAR DETECTION OF FMDV IN CATTLE AT SAVAR IN BANGLADESH
}

\author{
N. Jannat ${ }^{1}$, M.S. Rahman ${ }^{1}$, E. Islam ${ }^{2}$, N.A. Rumi ${ }^{3}$, M. Giasuddin ${ }^{2}$, M. Hasan', \\ M.R. Islam ${ }^{4}$ and M.Z. Hassan ${ }^{2 *}$ \\ ${ }^{1}$ Department of Medicine, Surgery and Obstetrics, Hajee Mohammad Danesh Science and \\ Technology University, Dinajpur, Bangladesh \\ ${ }^{2}$ Animal Health Research Division, Bangladesh Livestock Research Institute \\ Savar, Dhaka-1341, Bangladesh \\ ${ }^{3}$ Department of Microbiology, Hajee Mohammad Danesh Science and Technology \\ University, Dinajpur, Bangladesh \\ ${ }^{4}$ Livestock Division, Bangladesh Agricultural Research Council, Farmgate, Dhaka-1215
}

\begin{abstract}
The study was conducted to observe the overall seroprevalence and molecular detection of circulating FMD virus from infected cattle and efficacy of antibacterial drugs against secondary bacterial infection at Savar, Dhaka from January- December 2018. A total of 92 serum samples were collected for indirect c-ELISA to detect antibodies against non-structural proteins of FMD virus, and overall seroprevalence was $94.02 \%$. The seroprevalence of serotype $\mathrm{O}$ and $\mathrm{A}$ was higher $(95.83 \%$ and $95.83 \%)$ in male cattle than female $(93.18 \%$ and $90.91 \%)$ respectively. 6 Months to 3 years aged cattle showed, significantly $(p<0.01)$ higher seroprevalence $(100 \%)$ than above 4 years age groups for serotype $O(82.14 \%)$ and A $(78.57 \%)$. Local cattle were more seropositive $96.88 \%$ compared to crossbred cattle $93.33 \%$ for serotype $\mathrm{O}$ and $91.67 \%$ for serotype $\mathrm{A}$ and this variation was not statistically significant $(p>0.05)$. Among 10 clinical samples of FMD from infected cattle, 8 samples were positive for different serotypes, among them 2 each were identified as serotype $A$ and Asia-1. On the other hand,4 samples were identified as mixed infection (1 sample of serotype O+A, 3 samples of O+Asia-1) by mRT-PCR. In this study on therapeutic intervention with sulphadimidine significantly $(p<0.05)$ reduced the clinical signs of FMD than Gentamycin and Ampicillin. The higher seroprevalence of the disease has substantial economic implications which signify the need for devising effective control measure. However, the detection of ' $\mathrm{O}$ ', Asia-1and ' $A$ ' serotype emphasizes the critical need for use of atrivalent vaccine in the field.
\end{abstract}

Keywords: FMDV, Cattle, c-ELISA, mRT-PCR.

\footnotetext{
*Corresponding author: zhtitas@gmail.com, zakir.vet@blri.gov.bd
} 
Jannat et al.

\section{INTRODUCTION}

Foot and Mouth Diseases (FMD) is the most fatal and contagious viral disease of cloven hoofed animal like cattle (Smith et al., 2014), and listed as A grade disease according to OIE. Locally, FMD is known as Khuraroag. FMD virus (FMDV) belongs to the genus Apthovirus under the family Picornaviridae (OIE, 2012). There are seven serotypes of FMDV like A, O, C, Asia 1, SAT-1, SAT-2, SAT-3 and no cross-protection between the serotype and even after vaccination (Mumford, 2007). FMDV has four surface proteins notably, VP1, VP2, VP3 and VP4, in which VP4 has a significant role in viral attachment, protective immunity and serotype specificity (Bittle et al., 1982). The clinical sign included high fever (104-106 ${ }^{\circ} \mathrm{F}$ ), water soap like profuse salivation, ulceration in mouth, tongue, gum, sometimes eruption of whole tongue epithelium, ulceration in soft tissue on inter digital space of hooves, dehydration, calf mortality, low production performance in infected animal. Meanwhile it was alarming that recovered animal shown half of the initial production performance. Death occurs due to FMDV mostly in calves and known as tiger heart disease (Siddique et al., 2018). In Bangladesh FMD is endemic and the most fatal economic diseases in the livestock sector. It is estimated,180 billion BD TK losses due to FMD yearly (Giasuddin et al., 2016). Among the serotypes A, O,C, Asia 1 are circulating in this territory (Loth etal., 2011). There are about 25 million cattle, 25 million goats, 1.4 million buffalo and 3.4 million sheep in Bangladesh (Livestock Economy, 2017-18, Bangladesh). Due to the high density of the cattle population, FMD outbreak spreads rapidly in Bangladesh. Moreover it is a transboundary animal disease and every year huge infection occurred due to animal movement (Siddique et al., 2018). Meanwhile, clinical signs are the first sight for FMD identification but for confirmatory laboratory diagnosis is necessary like complement fixation test (CFT), virus neutralization test (VNT) etc. However, Reverse Transcriptase Polymerase Chain reaction (RT-PCR) is routinely used for confirmation of FMDV throughout the world. In addition, detection of the antibody levels due to natural infection by FMDV or vaccination against FMDV, Enzyme Linked Immunorosbent Assay (ELISA) is used for proper sero-monitoring (Sil et al., 2000 and Mohapatra et al., 2018).FMD is a viral disease, but to check the secondary bacterial infection, practitioners used antibacterial drug along with other supportive treatment. Therefore, keeping in view the importance of FMD in Bangladesh this study was designed for seroprevalence and molecular detection of FMDV in a selected area of Bangladesh along with evaluation of drug efficacy against secondary bacterial infection.

\section{MATERIALS AND METHODS}

\section{Location and Period of Study}

The study was carried out in different areas of Savar Upazila under Dhaka district from January to December 2018. The molecular and serological works were done in Foot and Mouth Disease (FMD) Research laboratory, Bangladesh Livestock Research Institute (BLRI), Savar, Dhaka (Annex 1). 


\section{Sample Collection}

A total of 92 blood serum samples were randomly collected from vaccinated cattle according to their age, sex and breed and 10 clinical samples (tongue epithelium) from infected cattle. Tissue samples were immediately transported with medium containing equal volumes of glycerol and phosphate-buffered saline ( $\mathrm{pH}$ 7.2-7.6) and $2 \%$ antibiotic-antimycotic to the laboratory on ice. Blood samples were collected from the jugular vein of cattle through the venipuncture method by using sterile 10 $\mathrm{ml}$ needle and syringe.

\section{Serum preparation and ELISA Test:}

Collected blood was kept at least 3-4 hours at room temperature in a slightly inclined position to facilitate clotting and separation of serum. The collected sera were stored at $-20^{\circ} \mathrm{C}$ until use. The ELISA test was carried out from serum by using Indirect ELISA kit manufactured by ID.Vet ${ }^{\circledR}$ Innovative Diagnostics, France according to the manufacture's protocol.

\section{Inoculum Preparation and RNA Extraction}

Piece of the epithelial tissue was removed from the glycerol buffer, blotted dry on absorbent paper to reduce the glycerol content. Approximately 1-2 gm tissue was weighted by an electric balance and homogenized by grinding with sterilized mortar and pestle. Then $20 \%$ suspension was prepared by adding phosphate buffer saline. The suspension of each of the samples was then centrifuged at 3,000 rpm for 10 minutes maintaining the temperature at $4^{\circ} \mathrm{C}$. The supernatant of each of the samples was taken for further processing according to the OIE manual. For the sterility test, a little number of inoculums was inoculated into bacteriological media to identify the presence of any type of bacteria. RNA extraction was carried out from FMD inoculums by using the QIAamp® Viral RNA kit (Qiagen, Germany) according to the manufacture's protocol.

\section{Conventional Reverse Transcription Polymerase Chain Reaction (RT-PCR)}

The target in the genome was amplified by one step RT-PCR using the FMD universal and serotype specific primer (Reid et al., 2000). Primer details were mentioned in following table (Table.1).

Table 1. Different Primer label with PCR products (bp)

\begin{tabular}{l|l|l|l|l|l}
\hline $\begin{array}{l}\text { FMD } \\
\text { serotypes }\end{array}$ & $\begin{array}{l}\text { Primer } \\
\text { label }\end{array}$ & Sequence(5'-3') & Location & $\begin{array}{l}\text { PCR } \\
\text { products } \\
(\mathrm{bp})\end{array}$ & Reference \\
\hline $\begin{array}{l}\text { All } \\
\text { serotypes }\end{array}$ & $\mathrm{P}_{33}$ & AGCTTGTACCAGGGTTTGGC & $2 \mathrm{~B}$ & 328 & $\begin{array}{l}\text { Vangrysperre } \\
\text { and De Clercq, }\end{array}$ \\
$\mathrm{O}$ & $\mathrm{P}_{38}$ & GCTGCCTACCTCCTTCAA & $1 \mathrm{D}$ & 402 & $(1996)$ \\
Asia-1 & $\mathrm{P}_{74}$ & GACACCACTCAGGACCGCCG & $1 \mathrm{D}$ & 292 & \\
A & $\mathrm{P}_{110}$ & ATGCA(G:A:T:C)AC(G:A:T:C) CAC & $1 \mathrm{D}$ & 732 & $\begin{array}{l}\text { Callens and De } \\
\text { Clercq, (1997) }\end{array}$ \\
\hline
\end{tabular}


The amplification was performed on a thermal cycler with one step RT-PCR kit (Qiagen, Germany) with one cycle of reverse transcription conditions of $50^{\circ} \mathrm{C}$ for 30 min and $95^{\circ} \mathrm{C}$ for $10 \mathrm{~min}$ and followed by 30 cycles of $94{ }^{\circ} \mathrm{C}$ for $1 \mathrm{~min}, 55^{\circ} \mathrm{C}$ for 1 sec (type A), $55^{\circ} \mathrm{C}$ for $30 \mathrm{sec}$ (type $\mathrm{O}$ ) and $72^{\circ} \mathrm{C}$ for $1 \mathrm{~min}$ and finally one cycle of final extension of $72^{\circ} \mathrm{C}$ for $10 \mathrm{~min}$. After PCR, the amplified products were visualized by agarose gel electrophoresis using $2 \%$ agarose gel containing $0.6 \mathrm{mg} / \mathrm{ml}$ ethidium bromide at $100 \mathrm{~V}$ in $1 \mathrm{X}$ tris borate EDTA (TBE) buffer. At the end of electrophoresis, the gel was documented on a UV transiluminator (AlphaImager®Mini System, USA).

\section{Grouping of animal for Antibiotic therapy:}

A total of 30 FMD affected cattle were used for the study. The animals were divided into three treatment groups each containing 10 animals (Table 2).

Table 2. Details of treatment groups of cattle.

\begin{tabular}{c|c|c|c}
\hline Group & Drug used & Dosage & Treatment days \\
\hline Group A & Sulphadimidine & $30 \mathrm{ml} / 50 \mathrm{~kg}$ body weight (I/M) & 7 \\
Group B & Gentamycin & $12 \mathrm{ml} / 100 \mathrm{~kg}$ body weight (I/M) & 7 \\
Group C & Ampicillin & $8 \mathrm{ml} / 100 \mathrm{~kg}$ body weight (I/M) & 7 \\
\hline
\end{tabular}

\section{Statistical Analysis}

The data obtained from this study were subjected to descriptive statistics (Tables and charts), Chi-square test of independence and odds ratio (OR) to determine the association of the variables (age, sex, species and breed) with the presence of FMD virus antibodies. The value of $\mathrm{p}<0.05$ was considered significant in this study. Descriptive statistics was carried out using Microsoft excel 2007. Chi square, odds ratio and confidence intervals were calculated using IBM SPSS 15 software.

\section{RESULTS}

\section{Results of ELISA test:}

A total of 92 serum samples were collected for indirect c-ELISA to detect antibodies against non-structural proteins of FMD virus, and overall seroprevalence was 94.02\%. The seroprevalence of serotype $\mathrm{O}$ and $\mathrm{A}$ was higher $(95.83 \%$ and $95.83 \%)$ (Table 3 and Table 4) in male cattle than female (93.18\% and 90.91\%) (Table 5 and 6) respectively. 6 Months to 3 years aged cattle showed, significantly $(\mathrm{p}<0.01)$ higher seroprevalence $(100 \%)$ than above 4 years age groups for serotype $\mathrm{O}(82.14 \%)$ and $\mathrm{A}$ (78.57\%) (Table 7 and 8). Local cattle was more seropositive $96.88 \%$ compared to crossbred cattle $93.33 \%$ for serotype $\mathrm{O}$ and $91.67 \%$ for serotype A (Table 9 and 10) and this variation was not statistically significant $(\mathrm{p}>0.05)$. 
Table 3. Seroprevalence of serotype O of FMD in Cattle

\begin{tabular}{c|c|c|c|c|c|c}
\hline \multirow{2}{*}{$\begin{array}{c}\text { Total no. of } \\
\text { cattle serum } \\
\text { examined }\end{array}$} & \multicolumn{2}{|l|}{ No. of positive } & \multicolumn{2}{l|}{ No. of negative } & \multicolumn{2}{|c}{ Doubtful } \\
\cline { 2 - 8 } & No. & $\begin{array}{c}\text { Prevalence } \\
(\%)\end{array}$ & No. & $\begin{array}{c}\text { Prevalence } \\
(\%)\end{array}$ & No. & $\begin{array}{c}\text { Prevalence } \\
(\%)\end{array}$ \\
\hline 92 & 87 & 94.57 & 5 & 5.43 & 0 & 0 \\
\hline
\end{tabular}

Table 4. Seroprevalence of serotype A FMD in Cattle

\begin{tabular}{c|c|c|c|c|c|c}
\hline \multirow{2}{*}{$\begin{array}{c}\text { Total no. of } \\
\text { cattle serum } \\
\text { examined }\end{array}$} & \multicolumn{2}{|c|}{ No. of positive } & \multicolumn{2}{c|}{ No. of negative } & \multicolumn{2}{c}{ Doubtful } \\
\cline { 2 - 7 } & No. & $\begin{array}{c}\text { Prevalence } \\
(\%)\end{array}$ & No. & $\begin{array}{c}\text { Prevalence } \\
(\%)\end{array}$ & No. & $\begin{array}{c}\text { Prevalence } \\
(\%)\end{array}$ \\
\hline 92 & 86 & 93.48 & 5 & 5.43 & 1 & 1.087 \\
\hline
\end{tabular}

Table 5. Sex-wise seroprevalence of serotype O FMD in Cattle

\begin{tabular}{|c|c|c|c|c|c|c|c|c|c|}
\hline \multirow[b]{2}{*}{ Sex } & \multirow{2}{*}{$\begin{array}{c}\text { No. of } \\
\text { cattle } \\
\text { Examined }\end{array}$} & \multicolumn{2}{|c|}{ No. of positive } & \multicolumn{2}{|c|}{ No. of Negative } & \multicolumn{2}{|c|}{ Doubtful } & \multirow[b]{2}{*}{$\chi^{2}$} & \multirow{2}{*}{$\begin{array}{c}\text { Level of } \\
\text { significance(p } \\
\text {-value) }\end{array}$} \\
\hline & & No. & $\begin{array}{c}\text { Prevalence } \\
(\%)\end{array}$ & No. & $\begin{array}{c}\text { Prevalence } \\
(\%)\end{array}$ & No. & $\%$ & & \\
\hline Male & 48 & 46 & 95.83 & 2 & 4.17 & 0 & 0 & .314 & $.576(\mathrm{NS})$ \\
\hline Female & 44 & 41 & 93.18 & 3 & 6.82 & 0 & 0 & & \\
\hline
\end{tabular}

NS means non-significant $(\mathrm{P}>0.05)$

Table 6. Sex-wise seroprevalence of serotype A FMD in Cattle

\begin{tabular}{|c|c|c|c|c|c|c|c|c|c|}
\hline \multirow[b]{2}{*}{ Sex } & \multirow{2}{*}{$\begin{array}{c}\text { No. of } \\
\text { cattle } \\
\text { Examined }\end{array}$} & \multicolumn{2}{|c|}{ No. of positive } & \multicolumn{2}{|c|}{ No. of Negative } & \multicolumn{2}{|c|}{ Doubtful } & \multirow[b]{2}{*}{$\chi^{2}$} & \multirow{2}{*}{$\begin{array}{c}\text { Level of } \\
\text { significance } \\
\text { (p-value) }\end{array}$} \\
\hline & & No. & $\begin{array}{c}\text { Prevalence } \\
(\%)\end{array}$ & No. & $\begin{array}{c}\text { Prevalence } \\
(\%)\end{array}$ & No. & $\%$ & & \\
\hline Male & 48 & 46 & 95.83 & 2 & 4.17 & 0 & 0 & \multirow{2}{*}{1.447} & \multirow[t]{2}{*}{$.485(\mathrm{NS})$} \\
\hline Female & 44 & 40 & 90.91 & 3 & 6.82 & 1 & 2.27 & & \\
\hline
\end{tabular}

NS means $(\mathrm{P}>0.05)$ 
Table 7. Age-wise seroprevalence of serotype O FMD in Cattle

\begin{tabular}{|c|c|c|c|c|c|c|c|c|c|}
\hline \multirow{2}{*}{ Aged groups } & \multirow{2}{*}{$\begin{array}{l}\text { No. of } \\
\text { tested }\end{array}$} & \multicolumn{2}{|c|}{$\begin{array}{c}\text { No. of Positive } \\
\text { case }\end{array}$} & \multicolumn{2}{|c|}{$\begin{array}{c}\text { No. of Negative } \\
\text { case }\end{array}$} & \multicolumn{2}{|c|}{ Doubtful } & \multirow{2}{*}{$\chi^{2}$} & \multirow{2}{*}{$\begin{array}{l}\text { Level of } \\
\text { significance } \\
\text { (p-value) }\end{array}$} \\
\hline & & No. & $\begin{array}{c}\text { Prevalence } \\
(\%)\end{array}$ & No. & $\begin{array}{c}\text { Prevalence } \\
(\%)\end{array}$ & No. & $(\%)$ & & \\
\hline $\begin{array}{c}\text { Group } 1 \\
\text { (>6 months-1 } \\
\text { year) }\end{array}$ & 30 & 30 & 100 & 0 & 0 & 0 & 0 & & \\
\hline $\begin{array}{c}\text { Group } 2 \\
(>2-3 \text { years })\end{array}$ & 34 & 34 & 100 & 0 & 0 & 0 & 0 & 12.085 & $.002 * *$ \\
\hline $\begin{array}{c}\text { Group } 3 \\
\text { (>4 years) }\end{array}$ & 28 & 23 & 82.14 & 5 & 17.87 & 0 & 0 & & \\
\hline
\end{tabular}

$* * \mathrm{P}$ value $<0.01$

Table 8. Age-wise seroprevalence of serotype A FMD in Cattle

\begin{tabular}{|c|c|c|c|c|c|c|c|c|c|}
\hline \multirow{2}{*}{ Aged groups } & \multirow{2}{*}{$\begin{array}{l}\text { No. of } \\
\text { tested }\end{array}$} & \multicolumn{2}{|c|}{$\begin{array}{c}\text { No. of Positive } \\
\text { case }\end{array}$} & \multicolumn{2}{|c|}{$\begin{array}{c}\text { No. of Negative } \\
\text { case }\end{array}$} & \multicolumn{2}{|c|}{ Doubtful } & \multirow{2}{*}{$\chi^{2}$} & \multirow{2}{*}{$\begin{array}{c}\text { Level of } \\
\text { significance } \\
\text { (p-value) }\end{array}$} \\
\hline & & No. & $\begin{array}{c}\text { Prevalence } \\
(\%)\end{array}$ & No. & $\begin{array}{c}\text { Prevalence } \\
(\%)\end{array}$ & No. & $(\%)$ & & \\
\hline $\begin{array}{c}\text { Group } 1 \\
(>6 \text { months- } \\
1 \text { year) }\end{array}$ & 30 & 30 & 100 & 0 & 0 & 0 & 0 & & \\
\hline $\begin{array}{c}\text { Group } 2 \\
(>2-3 \text { years })\end{array}$ & 34 & 34 & 100 & 0 & 0 & 0 & 0 & 14.671 & $.005^{*}$ \\
\hline $\begin{array}{l}\text { Group } 3 \\
\text { (>4 years) }\end{array}$ & 28 & 22 & 78.57 & 5 & 17.87 & 1 & 3.57 & & \\
\hline
\end{tabular}

$* \mathrm{P}$ value $<0.05$

Table 9. Breed-wise Seroprevalence of serotype O FMD in Cattle

\begin{tabular}{|c|c|c|c|c|c|c|c|c|c|}
\hline \multirow{2}{*}{ Breed } & \multirow{2}{*}{$\begin{array}{c}\text { No. of } \\
\text { Goat } \\
\text { Examined }\end{array}$} & \multicolumn{2}{|c|}{$\begin{array}{c}\text { No. of } \\
\text { Seropositive }\end{array}$} & \multicolumn{2}{|c|}{$\begin{array}{c}\text { No. of } \\
\text { Seronegative }\end{array}$} & \multicolumn{2}{|c|}{ Doubtful } & \multirow{2}{*}{$\chi^{2}$} & \multirow{2}{*}{$\begin{array}{l}\text { Level of } \\
\text { significance } \\
\text { (p-value) }\end{array}$} \\
\hline & & No. & $\begin{array}{c}\text { Prevalence } \\
(\%)\end{array}$ & No. & $\begin{array}{c}\text { Prevalence } \\
(\%)\end{array}$ & No. & $\begin{array}{l}\text { Prevalence } \\
(\%)\end{array}$ & & \\
\hline Cross breed & 60 & 56 & 93.33 & 4 & 6.67 & 0 & 0 & \multirow[b]{2}{*}{0.509} & \multirow[b]{2}{*}{$0.475(\mathrm{NS})$} \\
\hline $\begin{array}{l}\text { Indigenous } \\
\text { breed }\end{array}$ & 32 & 31 & 96.88 & 1 & 3.13 & 0 & 0 & & \\
\hline
\end{tabular}

NS means $(P>0.05)$ 
Table 10. Breed-wise Seroprevalence of serotype A FMD in Cattle

\begin{tabular}{|c|c|c|c|c|c|c|c|c|c|}
\hline \multirow[t]{2}{*}{ Breed } & \multirow{2}{*}{$\begin{array}{c}\text { No. of } \\
\text { Goat } \\
\text { Examined }\end{array}$} & \multicolumn{2}{|c|}{$\begin{array}{c}\text { No. of } \\
\text { Seropositive }\end{array}$} & \multicolumn{2}{|c|}{$\begin{array}{c}\text { No. of } \\
\text { Seronegative }\end{array}$} & \multicolumn{2}{|c|}{ Doubtful } & \multirow{2}{*}{$\chi^{2}$} & \multirow{2}{*}{$\begin{array}{c}\text { Level of } \\
\text { significance(p- } \\
\text { value) }\end{array}$} \\
\hline & & No. & $\begin{array}{c}\text { Prevalence } \\
(\%)\end{array}$ & No. & $\begin{array}{c}\text { Prevalence } \\
(\%)\end{array}$ & No. & $\%$ & & \\
\hline Cross breed & 60 & 55 & 91.67 & 4 & 6.67 & 1 & 1.67 & 1.076 & .584 \\
\hline $\begin{array}{l}\text { Indigenous } \\
\text { breed }\end{array}$ & 32 & 31 & 96.88 & 1 & 3.13 & 0 & 0 & & (NS) \\
\hline
\end{tabular}

NS means $(\mathrm{P}>0.05)$

Efficacy of antibacterial drugs against secondary bacterial infection in FMD of cattle:

Among the FMDV infected cattle, 30 animals were selected for antibacterial treatment against secondary bacterial infection. The antibacterial efficacy of Sulphadimidine (Diadin ${ }^{\circ}$, Reneta Ltd.), Gentamycin (Genacyn-Vet ${ }^{\circledR}$, Square Ltd.) and Ampicillin (Ampicin-vet ${ }^{\circledR}$, Square Ltd.) were determined on the basis of recovery of the disease showed in Table 13. The present study was demonstrated the excellent efficacy of Sulphadimidine @ 30ml $/ 50 \mathrm{~kg}$ body weight against secondary bacterial infection of FMD that significantly $(\mathrm{P}<0.05)$ reduced the lesions of FMD within $6.0 \pm 0.32$ days than Gentamycin @ $12 \mathrm{ml} / 100 \mathrm{~kg}$ body weight and Ampicillin @ $8 \mathrm{ml} / 100 \mathrm{~kg}$ body weight that took recovery period of $7.4 \pm 0.25$ and $7.9 \pm 0.37$ days respectively (Table 11). Sulphadimidine injection was found more effective to control the secondary bacterial infections and healing of FMD lesion than the other Gentamycin and Ampicillin.

Table 11. Efficacy of antibacterial drugs against secondary bacterial infection in FMD of cattle

\begin{tabular}{|c|c|c|c|c|}
\hline $\begin{array}{l}\text { Name of } \\
\text { the group }\end{array}$ & $\begin{array}{l}\text { No. of } \\
\text { animal } \\
\text { treated }\end{array}$ & Name of antibiotic & $\begin{array}{l}\text { Dose \& route of } \\
\text { administration }\end{array}$ & $\begin{array}{l}\text { Range of } \\
\text { complete } \\
\text { recovery days } \\
(\text { Mean } \pm \text { SE) }\end{array}$ \\
\hline Group-A & 10 & Sulphadimidine & $\begin{array}{c}\text { @ } 30 \mathrm{ml} / 50 \mathrm{~kg} \text { body wt. i/mly } \\
\text { on the } 1^{\text {st }} \text { day then } 1 / 2 \text { dose } \\
\text { daily for } 7 \text { days }\end{array}$ & $6.0 \pm 0.32^{\mathrm{a}}$ \\
\hline Group-B & 10 & Gentamycin & $\begin{array}{l}\text { @ } 12 \mathrm{ml} / 100 \mathrm{~kg} \text { body wt. } \\
\text { i/mly daily for } 7 \text { days }\end{array}$ & $7.4 \pm 0.25^{\mathrm{b}}$ \\
\hline \multirow[t]{2}{*}{ Group-C } & 10 & Ampicillin & $\begin{array}{c}\text { @ } 8 \mathrm{ml} / 100 \mathrm{~kg} \text { body wt. } \mathrm{i} / \mathrm{mly} \\
2 \text { times at } 1^{\text {st }} \text { day then } 1 \text { time } \\
\text { daily for } 76.0 \text { days }\end{array}$ & $7.9 \pm 0.37^{\mathrm{b}}$ \\
\hline & \multicolumn{3}{|c|}{ Level of significance } & $0.04 *$ \\
\hline
\end{tabular}

$* \mathrm{P}$ value $<0.05$ 


\section{Results of RT-PCR test:}

Samples from cattle of different ages were collected from Savarupazila of Bangladesh during the year 2018. It was found that out of 10 suspected samples, 2 were positive for FMDV serotype A, 2 were positive for FMDV serotype Asia 1, while 4 samples were positive for mixed infection. So, out of total tested samples, $80 \%$ samples were positive for FMD virus (Figure 1)

$\begin{array}{lllllllllll}1 & 2 & 3 & 4 & 5 & 6 & 7 & 8 & 9 & 10 & 11\end{array}$

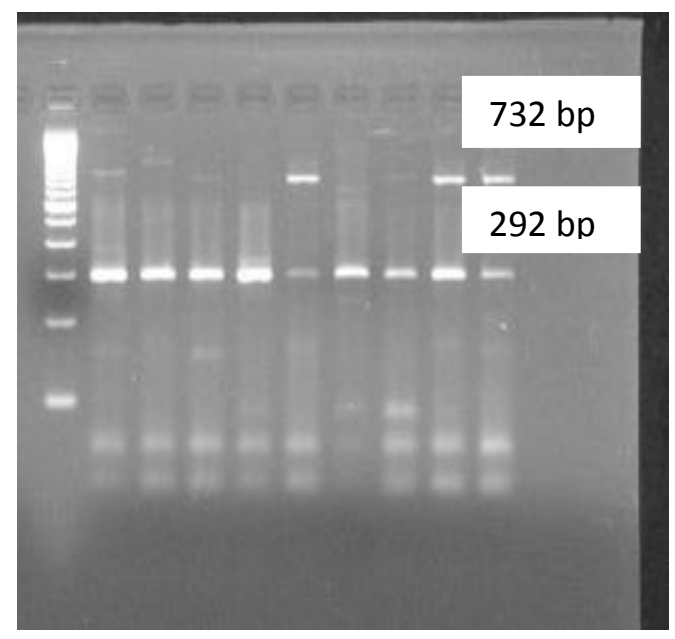

Figure 1

\section{$\begin{array}{llllllllll}1 & 2 & 3 & 4 & 5 & 6 & 7 & 8 & 9 & 10\end{array}$}

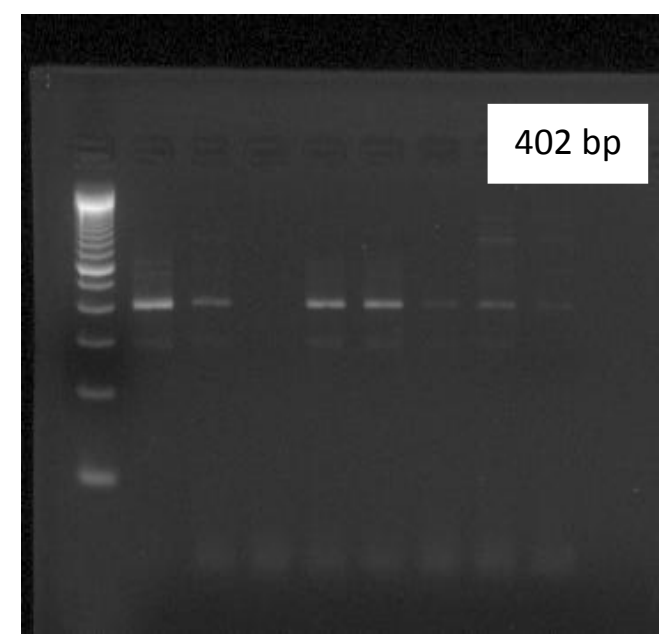

Figure 2

Figure 1 and 2: Electrophoresis of RT-PCR products on 2\% agarose gel stained with ethidium bromide. In figure 1; Lane 1: $1 \mathrm{~KB}$ plus DNA ladder (Invitrogen, USA), lane 2: Positive control, lane 3, 4, 5, 7, 8: FMDV Asia 1 serotype, lane 6, 9, 10: FMDV A serotype, lanes 11: Negative control (RNase-free water). In figure 2; Lane 1: $1 \mathrm{~KB}$ plus DNA ladder (Invitrogen, USA), lane 2: Positive control, lane 3, 5, 6: FMDV O serotype, lanes 7: Negative control (RNase-free water).

In conventional RT-PCR, amplification of RNA dependent RNA polymerase gene of foot and mouth disease virus yielded 402 bp for serotype O, 732 bp for serotype A and 292 bp for serotype Asia 1 virus and no amplification in negative template control (Figure1 \&2). Total time required to complete the RT-PCR including extraction of viral RNA is about $5 \mathrm{~h}$.

\section{DISCUSSION}

\section{Seroprevalence of Foot and Mouth Disease in cattle}

In Bangladesh, trivalent FMD vaccine is used by the Government to control the diseases throughout the country. The strains used in trivalent FMD vaccine is A, O and Asia 1 (Mahmud et al., 2018). Similar serotype vaccine seed is used in India for 
FMD control program (Raveendra Hegde et al., 2016). From the present study, the overall seroprevalence of FMD in both serotypes in cattle were $94.02 \%$. This finding was more or less similar to (Raveendra Hegde et al., 2016) which were 83-93\% in different districts of Karnataka.

\section{Foot and Mouth Disease Virus Detection in cattle}

In this study, Reverse Transcriptase Polymerase Chain Reaction (RT-PCR) shown that, $80 \%$ of samples were positive similar with the previous findings of Alam et al.(2015) by $83.33 \%$, Hossen et al. (2014) by $85.88 \%$, Reid et al. (2000) by $85 \%$ and lower than Kadir et al. (2014) by $90 \%$. Nawaz et al. (2014) by $89.40 \%$ and Saeed et al. (2010), who reported $87.20 \%$ specificity of the test with these primers respectively. FMDV serotype Asia-1(25\%) and serotype A (25\%) was mostly prevalent followed by Type O. Serotype 'Asia I', was detected in 2 (25\%) samples and $82 \%$ in different outbreak areas of Bangladesh (Siddique et al., 2018). However serotype $\mathrm{O}$ and $\mathrm{A}$ is more prevalent in Bangladesh than other serotypes, (Nandi et al., 2013). Although, Serotype Asia 1 was currently circulating FMDV in Bangladesh (Islam et al., 2017). Therefore, at present serotypes O, A and Asia 1 was actively circulating in Bangladesh (Hoor-E-Jannat et al., 2018).

\section{The effects of antibacterial drug against secondary bacterial infection due to} FMD:

The animal treated with Sulphadimidine was showed the recovery in $6.0 \pm 0.32^{\mathrm{a}}$ days where as the animal treated with Gentamycin and Ampicillin shown the recovery in $7.4 \pm 0.25^{\mathrm{b}}$ and $7.9 \pm 0.37^{\mathrm{b}}$ days respectively. Sulphadimidine injection was found more effective to control the secondary bacterial infections and healing of FMD lesion than Gentamycin and Ampicillin. The test result of group A was statistically significant compared to other group B and group C. This result was discussed and analyzed with field veterinarian with their experience. Actually, FMD is a viral diseases, no confirmatory treatment against FMD but antibiotic therapy was practiced widely to check secondary bacterial infection and to minimize the aggravate of the disease condition.

\section{CONCLUSIONS}

FMD is one of the major constraints for livestock development in Bangladesh. High economic losses due to calf mortality, reduced milk production, draft power and low body weight gain of beef fattening was seen. Moreover, it has no specific treatment. So, vaccination is the only way to prevent the outbreaks of the disease. Finally, these research findings proved that Serotype Asia-1, serotype O and serotype A of FMDV is promptly circulating in Bangladesh. Consequently, vaccination with local serotype given the protection against FMDV above $90 \%$ that obviously a clear message for FMD control program in this territory. 


\section{ACKNOWLEDGEMENT}

The authors were greatly acknowledged to Animal Health Research Division, BLRI, Savar, Dhaka and the development project "Research on FMD and PPR Research in Bangladesh" (Award no. 7080) of Ministry of Fisheries and Livestock, Bangladesh to conduct this research work for supporting laboratory facility and financial support.

\section{Conflicts of interest}

The authors have no any type of conflicts of interest to declare with others.

\section{REFERENCES}

Alam, M.A., Rahman, M., Hossen, M.L., Ahmed, S., Parvej, S., Khan, M.F.R. and Rahman, M.B. (2015). Reverse transcription polymerase chain reaction (RT-PCR) based detection and serotyping of FMD Virus from field samples of Gazipur, Bangladesh, and adaptation of the virus in BHK-21 cell. Journal of Advanced Veterinary and Animal Research, 2(3): 291-295.

Babangida, D., Ibrahim, A.A., Oladayo, F.O., Magaji, A.A., Alkali, B.R. and Jibril, A.H. (2017). Sero Survey of Foot and Mouth Disease Virus Infection in Cattle Crossing Some Major Border States in Northwestern Nigeria. Folia Veterinaria, 61(3): 12-18.

Bittle, J.L., Houghten, R.A., Alexander, H., Shinnick, T.M., Sutcliffe, J.G., Lerner, R.A. and Brown, F. (1982). Protection against foot-and-mouth disease by immunization with a chemically synthesized peptide predicted from the viral nucleotide sequence. Nature, 298(5869): 30.

Bangladesh Livestock Economy of Bangladesh (2017-18).www.dls.gov.bd

Chénard, G., Miedema, K., Moonen, P., Schrijver, R.S. and Dekker, A. (2003).A solid-phase blocking ELISA for detection of type $\mathrm{O}$ foot-and-mouth disease virus antibodies suitable for mass serology. Journal of Virological Methods, 107(1): 89-98.

Fanta D., Desalgn T., Bedaso M. and Tesfaye R. (2014). Epidemiological study on foot and mouth disease in cattle: Seroprevalence and risk factor assessment in KellemWollega Zone, West Ethiopia. African Journal of Agricultural Research. 9(18): 1391-1395.

Giasuddin, M., Mahmud, M.S., Alam, S.M.S., Samad, M.A., Islam, M.R., Ahasan, M.D. and Yousuf, M.A. (2016). Molecular epidemiology of foot-and-mouth disease viruses circulated in Bangladesh from 2011-2014. British Microbiology Research Journal, 16(4): 1-13.

Hegde, R., Kowalli, S., Nagaraja, K., Dharanesha, N.K., Seema, C.M., Khan, T.A. and Byregowda, S.M. (2016). Serosurveillance of foot and mouth disease in Karnataka state, India: a 3 years study. Virus Disease, 27(3): 294-302. doi:10.1007/s13337-016-0340-х

Hoor-E-Jannat, M., Islam, M.S., Bari, A.S.M., and Khan, M.A.H.N.A. (2018). Pathology, serotyping and phylogeny of foot and mouth disease viruses circulated in the cattle of Sirajganj district, Bangladesh. Indian Journal Veterinary Pathology, 42(1): 1-7.

Hossen, M.L., Ahmed, S., Khan, M.F.R., Rahman, M.T., Saha, S., Nazir, R.M. and Rahman, M.B. (2014). Typing of foot and mouth disease virus circulating in Bangladesh by reverse transcription polymerase chain reaction. Journal of Veterinary Advances, 4(12): 778-785. 
Islam, M.S., Habib, M.A., Saha, P.C., Das, P.M., and Khan, M.N. (2017). Distribution of foot and mouth disease virus serotypes in cattle of Bangladesh. SAARC Journal of Agriculture, 15(1): 33-42.

Kadir, A., and Ahmed, S. (2014). Identification of different serotypes of Foot and Mouth Disease Virus from Sylhet district, Bangladesh; by adoption and application of RTPCR and mRT-PCR. International Journal of Natural Sciences, 28-34.

Kibore, B., Gitao, C.G., Sangula, A., and Kitala, P. (2013).Foot and mouth disease seroprevalence in cattle in Kenya. Journal of Veterinary Medicine and Animal Health, 5(9): 262-268.

Loth, L., Osmani, M.G., Kalam, M.A., Chakraborty, R.K., Wadsworth, J., Knowles, N. J. and Benigno, C. (2011). Molecular characterization of foot-and-mouth disease virus: implications for disease control in Bangladesh. Transboundary and emerging diseases, 58(3): 240-246.

Mahmud M.S., Islam E, Samad M.A., Karim M.R., Saha A.K. and Giasuddin, M. (2017). Adaptation of Three Different BLRI Strain (O, A, Asia 1) of Foot and Mouth Disease Virus Serotypes in Baby Hamster Kidney-21 Cell Line. Immunology and Infectious Diseases. 2017 Oct; 5(2):11-5.

Mohapatra, J.K., Das, B., Rout, M., Sreenivasa, B.P., Subramaniam, S., Sanyal, A., and Pattnaik, B. (2018). Alternate vaccine strain selection in the wake of emerging footand-mouth disease virus serotype A antigenic variants in India. Vaccine, 36(23): 31913194.

Mumford, J.A. (2007). Vaccines and viral antigenic diversity. Revue Scientifique Et Technique-Office International Des Epizooties, 26(1), 69.

Nawaz, Z., Arshad, M., and Iqbal, Z. (2014).Epidemiology of foot and mouth disease in buffaloes and cattle of Punjab using non structural proteins ELISA. Pakistan Journal of Agricultural Sciences, 51(2).

OIE (2012). Foot and Mouth disease, Manual of Diagnostic Tests and Vaccines for Terrestrial Animals, Version adopted by the World Assembly of Delegates of the OIE in May 2012.

Reid, S.M., Ferris, N.P., Hutchings, G.H., Samuel, A.R., and Knowles, N.J. (2000). Primary diagnosis of foot-and-mouth disease by reverse transcription polymerase chain reaction. Journal of virological methods, 89(1-2): 167-176.

Sil, B.K. and Taimur, M.J.F.A. (2000). ELISA based techniques for the identification of footand-mouth disease virus and vaccine evaluation in Bangladesh.Joint FAO/IAEA Division of Nuclear Techniques in Food and Agriculture, Vienna (Austria); 136: 49-56.

Siddique, M. A., Ali, M.R., Alam, A.S.M.R.U., Ullah, H., Rahman, A., Chakrabarty, R. P. and Hossain, M.A. (2018). Emergence of two novel sublineages Ind2001 BD 1 and Ind2001 BD 2 of foot-and-mouth disease virus serotype $\mathrm{O}$ in Bangladesh. Transboundary and emerging diseases, 65(4): 1009-1023.

Smith, M.T., Bennett, A.M., Grubman, M.J. and Bundy, B.C. (2014). Foot-and-mouth disease: technical and political challenges to eradication. Vaccine, 32(31): 3902-3908.

Tekleghiorghis, T., Weerdmeester, K., van Hemert-Kluitenberg, F., Moormann, R.J. and Dekker, A. (2017). Foot-and-Mouth Disease Seroprevalence in Cattle in Eritrea. Transboundary and emerging diseases, 64(3): 754-763. 